\title{
Pengaruh Kepuasan Kerja Terhadap Komitmen Karyawan Rumah Sakit Mata Undaan Surabaya
}

\author{
The Effect of Job Satisfaction on Commitment of Rumah Sakit Mata Undaan \\ Surabaya's Employees
}

Intan Ayu Ningkiswari ${ }^{1}$, Ratna Dwi Wulandari ${ }^{2}$

${ }^{1,2}$ Fakultas Kesehatan Masyarakat, Universitas Airlangga Surabaya

E-mail: intan-ayu-13@unair.ac.id

\begin{abstract}
Preliminary survey result showed the number of employees knowledge about the event held by Undaan Eye Hospital in Surabaya reached $52,8 \%$. It means more than $20 \%$ employees are not aware of activity outside the work which that number can affect to decreasing employee commitment to the organization. Job satisfaction factors divided into 5 there are pay satisfaction, promotion, coworker, supervisor and the job characteristic. The aim of this study is to analyze the influence job satisfaction to employee commitment. Observational analytic was used in this research with the cross sectional design. The data was obtained through questionnaire with simple random sampling involving 62 employees as the sample of this research. The data obtained were analyzed using logistic regression test univariate $(\alpha=0,05)$ to examine the influence of Job satisfaction to employee commitment. The test result indicates that job satisfaction significantly influenced employee commitment at significance value of 0,02. Job satisfaction factors that there are influences toward employee commitment are employee's pay satisfaction (sig=0,001), promotion (sig=0,005), supervisor (sig=0,004) and job characteristic (sig=0,001). On the other hand, the employee's coworker satisfaction does not influence the employee commitment.
\end{abstract}

Keywords: employee commitment, job satisfaction, job satisfaction factors.

\begin{abstract}
ABSTRAK
Hasil survei pendahuluan menunjukkan rendahnya tingkat pengetahuan karyawan tentang kegiatan yang pernah diadakan Rumah Sakit Mata Undaan Surabaya mencapai 52,8\%. Artinya lebih dari $20 \%$ karyawan tidak mengetahui kegiatan di luar kerja yang berdampak pada penurunan komitmen karyawan terhadap organisasi. Faktor kepuasan kerja dibagi menjadi 5 yaitu kepuasan gaji, promosi, rekan kerja, atasan dan sifat pekerjaan. Tujuan penelitian ini adalah untuk mengetahui pengaruh kepuasan kerja terhadap komitmen karyawan. Penelitian ini adalah penelitian analitik observasional dengan desain rancang bangun cr oss sectional. Data diperolah melalui kuesioner dengan metode simple random sampling sehingga diperoleh 62 karyawan sebagai responden penelitian. Data yang diperoleh dianalisis menggunakan uji regresi logistik univariat $(\alpha=0,05)$ untuk menguji pengaruh kepuasan kerja terhadap komitmen karyawan. Hasil uji menunjukkan kepuasan kerja berpengaruh signifikan terhadap komitmen karyawan dengan nilai signifikansi 0,02 . Faktor kepuasan kerja yang berpengaruh terhadap komitmen karyawan meliputi kepuasan gaji $(\mathrm{sig}=0,001)$, promosi ( $\mathrm{sig}=0,005)$, atasan $(\mathrm{sig}=0,004)$ dan sifat pekerjaan $(\mathrm{sig}=0,001)$. Sedangkan faktor rekan kerja tidak berpengaruh signifikan terhadap komitmen karyawan.
\end{abstract}

Kata Kunci: faktor kepuasan kerja, kepuasan kerja, komitmen karyawan

\section{PENDAHULUAN}

Rumah Sakit sebagai suatu organisasi menghadapi dua jenis pelanggan sekaligus, yaitu pelanggan internal dan pelanggan eksternal (Tjiptono \& Diana, 2003). Pelanggan internal adalah pelanggan yang berasal dari dalam institusi tersebut yaitu karyawan institusi yang bersangkutan. Pelanggan eksternal merupakan konsumen pengguna jasa institusi. Penting bagi suatu institusi untuk berupaya meningkatkan kualitas layanan secara internal karena akan menentukan kepuasan kerja karyawannya. Karyawan dengan tingkat kepuasan yang tinggi cenderung akan meningkatkan kualitas layanannya dan akan berdampak pada kepuasan pelanggan eksternal dalam hal ini yaitu pengguna jasa rumah sakit.
Kepuasan kerja diartikan sebagai suatu respon emosional seseorang terhadap situasi dan kondisi kerja (Sopiah, 2008). Kepuasan kerja dirasakan setelah karyawan melakukan perbandingan antara apa yang diharapkan dari hasil kerjanya dengan apa yang sebenarnya dia peroleh dari hasil kerjanya. Rumah Sakit Mata Undaan Surabaya adalah rumah sakit swasta bertipe B yang memberikan pelayanan kesehatan mata tersier atau paripurna. Rumah sakit Mata Undaan Surabaya telah terakreditasi paripurna oleh Komite Asosiasi Rumah Sakit (KARS) Indonesia pada tahun 2013 dan berulang pada tahun 2016. Pihak manajemen Rumah Sakit Mata Undaan Surabaya secara rutin melakukan penilaian kepuasan karyawan setiap tahunnya. 
Suatu organisasi yang memiliki karyawan dengan tingkat kepuasan kerja tinggi cenderung lebih efektif dibandingkan organisasi dengan tingkat kepuasan kerja rendah (Robbins \& Judge, 2013). Kepuasan kerja bersifat individu, sehingga setiap karyawan memiliki kepuasan kerja yang berbeda sesuai dengan persepsinya terhadap pekerjaannya. Lebih lanjut dijelaskan beberapa perilaku sebagai wujud ketidakpuasan karyawan yaitu exit, voice, loyalty dan neglect. Exit yaitu perilaku karyawan yang mengarah pada pengunduran diri. Loyalty yaitu perilaku karyawan yang mencoba memperbaiki keadaan dengan memberikan saran perbaikan. Loyalty yaitu perilaku setia karyawan terhadap organisasi yang secara pasif menunggu kondisi membaik, sedangkan Neglect yaitu perilaku yang cenderung membiarkan kondisi memburuk didukung dengan meningkatnya tingkat absensi karyawan (Robbins \& Judge, 2013).

Survei pendahuluan yang dilaksanakan pada tahun 2017 diperoleh beberapa program atau kegiatan diluar pekerjaan yang pernah diadakan Rumah Sakit Mata Undaan Surabaya. Kegiatan di luar pekerjaan tersebut yaitu bakti sosial, jalan sehat, pelatihan, halal bihalal, Hari Ulang Tahun Rumah Sakit Mata Undaan Surabaya, gathering, akreditasi, rekreasi dan outbound. Responden dalam survei pendahuluan ini adalah karyawan tetap dan karyawan tidak tetap yang sudah bekerja minimal 1 tahun di Rumah Sakit Mata Undaan Surabaya. Hasilnya sebesar 47,2\% karyawan menjawab kurang dari 3 jenis kegiatan yang pernah diadakan Rumah Sakit Mata Undaan Surabaya sebesar $47,2 \%$, artinya pengetahuan responden terhadap kegiatan diluar pekerjaan Rumah Sakit Mata Undaan Surabaya masih rendah hanya mencapai $52,8 \%$. Berdasarkan survei pendahuluan diketahui partisipasi karyawan terhadap kegiatan yang diketahui sudah cukup bagus dibuktikan dengan 94,1\% karyawan telah ikut berpartisipasi pada kegiatan diluar pekerjaan yang mereka ketahui, sedangkan sisanya tidak berpartisipasi dengan alasan ada keperluan lain.

Pengetahuan karyawan terhadap kegiatan yang diadakan Rumah Sakit Mata Undaan Surabaya mempengaruhi tingkat partisipasi karyawan terhadap kegiatan rumah sakit. Partisipasi ini lah yang kemudian berdampak pada komitmen karyawan (Luthans, 2006). Komitmen karyawan berikaitan erat dengan alasan karyawan untuk mempertahankan diri dalam suatu organisasi. Komitmen karyawan diartikan sebagai suatu ikatan antara individu dengan organisasi ditandai dengan tiga karakteristik yaitu (a) Adanya keyakinan yang kuat dan penerimaan tujuan serta nilai yang dimiliki organisasi kerja; (b) Terdapat keinginan untuk mempertahankan diri agar tetap dapat menjadi anggota organisasi dan; (c) Adanya kemauan untuk berusaha keras sebagai bagian dari organisasi kerja (Allen \& Meyer, 1990). Maka dari itu, karyawan yang merasa puas cenderung mempunyai komitmen yang tinggi terhadap organisasi sehingga berdampak pada kinerja yang dihasilkan dan rendahnya angka turnover intention karyawan.

Penelitian ini bertujuan menguji pengaruh kepuasan kerja karyawan terhadap komitmen karyawan. Hasil dari penelitian ini diharapkan dapat menjadi pertimbangan bagi pihak manajemen Rumah Sakit Mata Undaan Surabaya untuk meningkatkan atau mempertahankan komitmen karyawan melalui faktor dominan kepuasan kerja yang mempengaruhi komitmen karyawan.

\section{METODE}

Penelitian ini adalah penelitian observasional analitik dengan rancang bangun cross sectional. Penelitian dilakukan di Rumah Sakit Mata Undaan Surabaya.Populasi dalam penelitian ini adalah karyawan Rumah Sakit Mata Undaan Surabaya berjumlah 169 orang. Besar sampel diperoleh berdasarkan rumus perhitungan simple random sampling, sehingga diperoleh sampel penelitian sebanyak 62 orang. Penentuan responden penelitian dilakukan secara acak tanpa melihat daftar nama sebelumnya. Karyawan di setiap unit kerja akan ditanya kesediaannya untuk berpartisipasi pada pengisian kuesioner. Karyawan yang bersedia dan telah mengisi kuesioner masuk menjadi responden dalam penelitian. Langkah ini berulang sampai diperoleh responden berjumlah 62 orang.

Data primer diperoleh melalui pengisian kuesioner oleh responden. Kuesioner penelitian menggunakan skala likert dengan pilihan jawaban Sangat Tidak Setuju, Tidak Setuju, Setuju, dan Sangat Setuju. Variabel independen dalam penelitian ini adalah kepuasan kerja yang terdiri dari kepuasan terhadap gaji, promosi, rekan kerja, atasan dan sifat pekerjaan diukur menggunakan kuesioner kepuasan kerja yang dikembangkan oleh Cellucci dan De Vries (1978). Terdapat 4 item pertanyaan untuk masing-masing faktor kepuasan kerja, sehingga total terdapat 20 pertanyaan kepuasan kerja karyawan. Pengukuran variabel dependen komitmen karyawan menggunakan instrumen Organizational Commitment Questionnaire yang dikembangkan oleh Allen dan Meyer (1990). Kuesioner tersebut terdiri dari 18 butir pertanyaan untuk mengukur ketiga dimensi komitmen yaitu komitmen afektif, komitmen berkelanjutan dan komitmen normatif, sehingga masing-masing dimensi diwakili oleh 6 butir pertanyaan (Allen \& Meyer, 1990). Skor total komitmen karyawan adalah penjumlahan dari ketiga dimensi komitmen dengan 18 butir pertanyaan. Kemudian dikelompokkan ke dalam kategori rendah, cukup dan tinggi. Masing-masing variabel independen diuji pengaruhnya terhadap variabel dependen menggunakan uji regresi logistik univariat dengan bantuan aplikasi uji statistik yaitu SPSS versi 21

\section{HASIL DAN PEMBAHASAN}

\section{Kepuasan Kerja Karyawan}

Kepuasan kerja karyawan merupakan persepsi kepuasan karyawan terhadap gaji, promosi, rekan kerja, atasan dan sifat pekerjaan yang dilakukan (Robbins \& Judge, 2008). Skor kepuasan kerja karyawan Rumah Sakit Mata Undaan Surabaya diperoleh dengan penjumlahan kelima faktor kepuasan kerja karyawan yang 
meliputi gaji, promosi, rekan kerja, atasan dan sifat pekerjaan. Kemudian hasil penjumlahan dikategorikan rendah, cukup dan tinggi.

Hasil penelitian kepuasan kerja menunjukkan sebanyak 53,2\% karyawan Rumah Sakit Mata Undaan Surabaya mempunyai kepuasan kerja yang tinggi. Sisanya sebanyak 46,8\% karyawan memiliki kepuasan kerja yang cukup. Tidak ditemukan karyawan Rumah Sakit Mata Undaan Surabaya yang memiliki kepuasan kerja dengan kategori rendah.

Faktor kepuasan kerja karyawan Rumah Sakit Mata Undaan diperoleh dari penjumlahan skor masing-masing pertanyaan indikator kepuasan terhadap gaji, promosi, rekan kerja, atasan dan pekerjaan. Kemudian dilakukan pengelompokkan hasil menjadi 3 kategori (rendah, cukup dan tinggi). Pada tabel 1 dijelaskan hasil pengukuran masingmasing faktor kepuasan kerja yang terdiri dari kepuasan gaji, promosi, rekan kerja, atasan dan sifat pekerjaan.

Tabel 1 menunjukkan bahwa tidak ada karyawan Rumah Sakit Mata Undaan yang memiliki kepuasan rendah pada tiap faktor kepuasan kerja karyawan. Kepuasan karyawan terhadap rekan kerja memiliki persentase paling tinggi pada kategori cukup yaitu sebesar 59,7\%. Secara keseluruhan dapat diketahui bahwa karyawan Rumah Sakit Mata Undaan memiliki kepuasan yang tinggi terhadap gaji, promosi, dan sifat pekerjaan.

Tabel 1. Hasil Pengukuran Indikator Kepuasan Gaji, Promosi, Rekan Kerja, Atasan dan Sifat Pekerjaan Karyawan Rumah Sakit Mata Undaan Surabaya Tahun 2017

\begin{tabular}{|c|c|c|c|}
\hline $\begin{array}{l}\text { Indikator Kepuasan } \\
\text { Keria }\end{array}$ & Kategori & Jumlah (orang) & Persentase (\%) \\
\hline \multirow[t]{4}{*}{ Gaji } & Rendah & 0 & 0 \\
\hline & Cukup & 30 & 48,4 \\
\hline & Tinggi & 32 & 51,6 \\
\hline & Total & 62 & 100 \\
\hline \multirow[t]{4}{*}{ Promosi } & Rendah & 0 & 0 \\
\hline & Cukup & 29 & 46,8 \\
\hline & Tinggi & 33 & 53,2 \\
\hline & Total & 62 & 100 \\
\hline \multirow[t]{4}{*}{ Rekan Kerja } & Rendah & 0 & 0 \\
\hline & Cukup & 37 & 59,7 \\
\hline & Tinggi & 25 & 40,3 \\
\hline & Total & 62 & 100 \\
\hline \multirow[t]{4}{*}{ Atasan } & Rendah & 0 & 0 \\
\hline & Cukup & 31 & 50 \\
\hline & Tinggi & 31 & 50 \\
\hline & Total & 62 & 100 \\
\hline \multirow{4}{*}{ Sifat Pekerjaan } & Rendah & 0 & 0 \\
\hline & Cukup & 36 & 41,9 \\
\hline & Tinggi & 26 & 58,1 \\
\hline & Total & 62 & 100 \\
\hline
\end{tabular}

Kepuasan terhadap gaji yang tinggi menunjukkan bahwa imbalan balas jasa berupa gaji yang diterima karyawan Rumah Sakit Mata Undaan Surabaya dianggap sudah kompetitif dan sesuai dengan tanggung jawab pekerjaan yang diterima (Robbins \& Judge, 2013). Kepuasan faktor promosi yang tinggi menunjukkan bahwa karyawan cenderung puas dengan sistem promosi yang berlaku termasuk standar yang digunakan untuk promosi dan sistem pelaksanaan promosi di Rumah Sakit Mata Surabaya. Karyawan yang memiliki kepuasan tinggi terhadap faktor sifat pekerjaan, itu artinya lima dimensi dasar pekerjaan menurut Robbins dan Judge (2008) sangat menentukan kepuasan karyawan yaitu variasi keterampilan, identitas tugas, signifikansi tugas, otonomi dan umpan balik sudah diperhatikan oleh pihak manajemen Rumah Sakit Mata Undaan Surabaya.

Variasi keterampilan adalah tingkat sejauh mana pekerjaan membutuhkan individu yang mampu melakukan beberapa keahlian dalam menyelesaikan tugas. Identitas tugas yaitu sejauh mana suatu pekerjaan memerlukan penyelesaian seluruh bagian pekerjaan yang diidentifikasi. Signifikansi tugas atau arti tugas yaitu sejauh mana pekerjaan memberikan dampak pada kehidupan atau pekerjaan orang lain. Otonomi yaitu tingkat sejauh mana pekerjaan memberikan kebebasan bagi karyawan dalam penyelesaiannya. Umpan balik yaitu sejauh mana aktivitas kerja membuat karyawan mengetahui keefektifan kinerjanya (Robbins \& Judge, 2008).

Persentase karyawan dengan kepuasan terhadap atasan terkategori cukup sama dengan persentase karyawan dengan kepuasan terhadap atasan terkategori tinggi, masing-masing peroleh persentase sebesar 50\%. Berdasarkan hasil penelitian diketahui terjalin hubungan yang bagus antara atasan dengan bawahan. Karyawan Rumah Sakit Mata Undaan Surabaya cenderung puas dengan sikap pimpinannya.

Kepuasan terhadap rekan kerja karyawan Rumah Sakit Mata Undaan tergolong cukup. Siagian (2013) menyatakan bahwa memiliki rekan kerja yang mendukung dapat meningkatkan kepuasan kerja karena mereka dapat saling 
memberikan bantuan dan motivasi dalam menyelesaikan pekerjaannya.

Dampak dari kepuasan kerja adalah kinerja karyawan, tingkat absensi dan tingkat turnover karyawan. Lebih lanjut dijelaskan bahwa kepuasan kerja mempengaruhi komitmen karyawan terlebih dahulu sebelum mempengaruhi kinerja karyawan (Robbins \& Judge, 2013).

\section{Komitmen Karyawan}

Komitmen karyawan menurut Robbins \& Judge (2008) adalah suatu keadaan ketika seorang karyawan memihak organisasi dan menerima tujuan organisasi, serta berusaha keras untuk tetap menjadi anggota dalam organisasi tempat ia bekerja. Komitmen afektif timbul ketika karyawan cenderung ingin menetap dalam suatu organisasi, sehingga karyawan menetap dalam suatu organisasi karena keinginannya sendiri untuk bekerja dan menjadi bagian dari organisasi tersebut. Komitmen bekelanjutan timbul jika karyawan ingin menetap menjadi karyawan karena menginginkan keuntungan atau manfaat yang diperoleh apabila menetap menjadi bagian organisasi. Komitmen normatif karyawan timbul dari karyawan nilai-nilai yang dipercayai oleh seorang karyawan. Karyawan yang memiliki komitmen normatif baik cenderung menganggap bahwa kesetiaan kepada organisasi tempat ia bekerja sekarang adalah suatu keharusan karena didukung persepsi karyawan yang menilai bahwa organisasinya layak mendapatkan kesetiaannya (Sopiah, 2008).

Skor komitmen karyawan diperoleh dari penjumlahan skor masing-masing dimensi komitmen karyawan yaitu dimensi komitmen afektif, komitmen keberlanjutan dan komitmen normatif. Kemudian hasil penjumlahan dikategorikan menjadi rendah, cukup dan tinggi. Hasil pengukuran komitmen karyawan Rumah Sakit Mata Undaan Surabaya dijelaskan pada tabel 2 .

Tabel 2. Hasil Pengukuran Komitmen Karyawan Rumah Sakit Mata Undaan Surabaya Tahun 2017

\begin{tabular}{lccr}
\hline \multicolumn{2}{c}{ Komitmen Karyawan } & Jumlah (orang) & Persentase (\%) \\
\hline Rendah & 0 & 0 \\
\hline Cukup & 29 & 46,8 \\
\hline Tinggi & Total & 33 & 53,2 \\
\hline & & 62 & 100 \\
\hline
\end{tabular}

Tabel 2 menunjukkan bahwa sebanyak $53,2 \%$ karyawan Rumah Sakit Mata Undaan Surabaya memiliki komitmen yang tinggi terhadap tempat kerja, sisanya sebanyak $46,8 \%$ karyawan memiliki komitmen terkategori cukup. Tidak ditemukan karyawan yang memiliki komitmen karyawan rendah.

Karyawan yang memiliki komitmen karyawan tinggi cenderung dipengaruhi oleh faktor personal, karakteristik pekerjaan, karakteristik organisasi dan pengalaman kerja (Sopiah, 2008). Faktor personal berkaitan dengan usia, jenis kelamin, tingkat pendidikan dan sifat karyawan. Karakteristik kerja yaitu tantangan dalam pekerjaan dan tingkat kesulitan pekerjaan bagi karyawan. Karakteristik struktur organisasi kaitannya dengan besar kecilnya organisasi tempat karyawan bekerja dan tingkat kendali karyawan dalam melaksanakan pekerjaan. Pengalaman kerja karyawan sangat berpengaruh pada tingkat komitmen karyawan.

Karyawan yang memiliki tingkat komitmen tinggi terhadap organisasi akan cenderung memiliki keinginan untuk memberikan usaha dan tanggung jawab yang lebih demi keberhasilan organisasinya (Allen \& Meyer, 1990). Oleh karena itu, karyawan dengan tingkat komitmen tinggi cenderung lebih memiliki tingkat kinerja yang baik karena karyawan cenderung ingin tetap bertahan di organisasi dan mencapai tujuan organisasi.

\section{Pengaruh Kepuasan Kerja terhadap Komitmen Karyawan}

Pengaruh kepuasan kerja terhadap komitmen karyawan Ruamh Sakit Mata Undaan Surabaya berdasarkan hasil uji regresi logistik univariat memiliki nilai signifikansi 0,002 yang artinya terdapat pengaruh kepuasan kerja terhadap komitmen karyawan karena nilai $p$ value $<\alpha(0,05)$. Nilai Exp (B) yang diperoleh adalah 0,269. Koefisien ini menunjukkan kuat pengaruh kepuasan kerja terhadap komitmen karyawan. Arti dari nilai Exp $(B)=0,269$ yaitu kemungkinan karyawan yang memiliki kepuasan tinggi akan berkomitmen cukup 3,72 (1/0,269) kali lebih besar jika dibandingkan dengan karyawan yang memiliki kepuasan kerja yang cukup. Maka dapat disimpulkan bahwa peningkatan kepuasan kerja cenderung dapat meningkatkan komitmen karyawan. Hasil penelitian ini mendukung penelitian Gondokusumo dan Sutanto (2015) yang dilaksanakan pada pekerja tetap suatu perusahaan dengan jumlah sampel 214 pekerja diperoleh hasil bahwa kepuasan kerja berpengaruh positif terhadap komitmen organisasional. Penelitian ini juga sejalan dengan penelitian terdahulu yang dilakukan Utama dan Wibawa (2016) pada karyawan perusahaan penyedia jasa penginapan Bali Rani Hotel, hasilnya kepuasan kerja berpengaruh secara signifikan terhadap komitmen karyawan terhadap organisasi. Penelitian yang dilakukan oleh Prabowo, et al., (2016) dengan judul "Pengaruh Kompensasi dan Kepuasan Kerja terhadap Komitmen Organisasional Perawat dan Bidan Kontrak di Rumah Sakit Bhayangkara Hasta Brata Batu Malang" menyatakan adanya pengaruh kepuasan kerja perawat dan bidan terhadap komitmen karyawan pada organisasi.

Kepuasan kerja terkait dengan terpenuhinya kebutuhan maupun keinginan karyawan oleh pihak organisasi, maka dengan sendirinya karyawan tersebut akan meningkatkan komitmen yang ada dalam dirinya. Variabel yang berpengaruh positif terhadap kepuasan kerja yaitu gaji/imbalan, kesempatan promosi, rekan kerja, atasan mereka dan sifat pekerjaan itu sendiri. 
Apabila kelima variabel tersebut terpenuhi dengan baik, maka komitmen terhadap organisasi akan timbul dengan baik (Luthans, 2006). Hasil uji pengaruh pada masing-masing faktor kepuasan kerja terhadap komitmen karyawan ditampilkan pada tabel 3 berikut.

Tabel 3 Hasil Uji Pengaruh Faktor Kepuasan Kerja terhadap Komitmen Karyawan Rumah Sakit Mata Undaan Surabaya Tahun 2017

\begin{tabular}{lccc}
\hline Faktor Kepuasan Kerja & P-Value $(\boldsymbol{\alpha}=\mathbf{0 , 0 5})$ & Exp (B) & Keterangan \\
\hline Gaji & 0,001 & 0,231 & Berpengaruh \\
\hline Promosi & 0,005 & 0,320 & Berpengaruh \\
\hline Rekan kerja & 0,842 & 0,923 & Tidak Berpengaruh \\
\hline Atasan & 0,004 & 0,292 & Berpengaruh \\
\hline Sifat pekerjaan & 0,0009 & 0,130 & Berpengaruh \\
\hline
\end{tabular}

Berdasarkan tabel 3 diketahui bahwa dari kelima faktor kepuasan kerja karyawan Rumah Sakit Mata Undaan Surabaya, empat diantaranya berpengaruh terhadap komitmen karyawan. Hanya faktor kepuasan terhadap rekan kerja yang tidak berpengaruh pada komitmen karyawan. Pengaruh kepuasan gaji terhadap komitmen karyawan berdasarkan hasil uji regresi logistik univariat memiliki nilai signifikansi 0,001 yang artinya terdapat pengaruh yang signifikan antara kepuasan gaji terhadap komitmen karyawan karena nilai $p$ value $<\alpha(0,05)$. Arti dari $\operatorname{Exp}(B)=0,231$ adalah kecenderungan karyawan yang memiliki kepuasan tinggi terhadap gaji akan mempunyai tingkat komitmen cukup 4,33 $(1 / 0,231)$ kali lebih besar jika dibandingkan dengan karyawan yang memiliki kepuasan gaji yang cukup. Maka dapat disimpulkan bahwa peningkatan kepuasan terhadap gaji cenderung akan meningkatkan komitmen karyawan. Penelitian yang dilakukan oleh Purwanti dan Anjarnako (2015) menunjukkan bahwa variabel kepuasan gaji merupakan faktor dominan yang mempengaruhi komitmen karyawan bagian administrasi PT. Perkebunan Nusantara X (persero) Unit Usaha Pabrik Gula Toelangan Sidoarjo.

Salah satu tujuan kompensasi terutama penggajian adalah untuk mempertahankan karyawan, apabila kompensasi dianggap tidak kompetitif dan tidak memenuhi prinsip keadilan, maka dampaknya dilihat pada tingginya keinginan karyawan untuk keluar (Hasibuan, 2013). Penting bagi organisasi untuk menerapkan prinsip equal pay for equal work atau pemberian imbalan yang sama untuk pekerjaan yang sama, dengan memperhatikan tingkat kesukaran dan tanggung jawab pekerjaan. Upaya yang dilakukan pihak Rumah Sakit Mata Undaan Surabaya dalam mempertahankan karyawannya selain memberikan gaji pokok yang sesuai ketentuan juga memberikan insentif pada karyawan sesuai kinerjanya pada bulan tersebut.

Hasil uji pengaruh kepuasan promosi terhadap komitmen karyawan Rumah Sakit Mata Undaan Surabaya juga signifikan dengan nilai $p$ value sebesar 0,005 yang artinya terdapat pengaruh secara signifikan antara kepuasan promosi terhadap komitmen karyawan karena nilai $p$-value < $\alpha(0,05)$. Nilai Exp (B) yang diperoleh adalah 0,320 artinya kemungkinan karyawan yang memiliki kepuasan tinggi terhadap promosi cenderung memiliki komitmen terkategori cukup $3,13(1 / 0,320)$ kali lebih besar dibandingkan karyawan dengan kepuasan promosi yang terkategori cukup. Maka dari itu dapat disimpulkan bahwa penerapan sistem promosi yang baik akan cenderung menciptakan komitmen karyawan yang tinggi. Karyawan akan cenderung merasa puas apabila berada pada tangga karir yang bagus dalam suatu organisasi (Siagian, 2013). Kepastian karir ini lah membuat karyawan berusaha meningkatkan komitmen terhadap organisasi, selain itu pelaksanaan promosi harus memenuhi beberapa asas seperti adanya jabatan yang belum terisi, kepercayaan karyawan terhadap skill seorang karyawan sehingga layak untuk mendapatkan promosi dan pelaksanaan promosi yang adil dan terbuka meningkatkan kepercayaan karyawan terhadap organisasi.

Pengaruh kepuasan rekan kerja terhadap komitmen karyawan Rumah Sakit Mata Undaan Surabaya memiliki nilai signifikansi 0,842 yang berarti lebih besar dari $\alpha(0,05)$. Dengan demikian tidak terdapat pengaruh secara signifikan faktor kepuasan rekan kerja terhadap komitmen karyawan. Hasil penelitian ini berlawanan dengan teori Robbins dan Judges (2008) yang menyebutkan bahwa kepuasan rekan kerja menjadi salah satu faktor yang mempengaruhi kepuasan kerja dan berdampak pada komitmen karyawan. Memiliki rekan kerja yang ramah dan mendukung menjadi salah satu alasan seorang karyawan untuk mempertahankan keanggotaannya di dalam suatu organisasi karena seseorang bekerja juga bertujuan untuk memenuhi kebutuhan interaksi sosial dengan rekan kerja. Hasil penelitian ini juga berlawanan dengan penelitian yang dilakukan oleh Purwanti dan Anjarnako (2015) yang menyatakan bahwa rekan kerja berpengaruh positif terhadap komitmen karyawan.

Hasil uji pengaruh faktor atasan terhadap komitmen karyawan menunjukkan bahwa atasan berpengaruh signifikan terhadap komitmen karyawan dengan signifikansi 0,004 ( $\alpha=0,05)$. Diperoleh nilai Exp $(B)=0,292$ maksudnya kecenderungan karyawan yang memiliki tingkat kepuasan tinggi terhadap atasan akan mempunyai tingkat komitmen cukup 3,42 $(1 / 0,292)$ kali lebih besar jika dibandingkan dengan karyawan yang memiliki kepuasan terhadap atasan yang terkategori cukup. Semakin baik sikap atasan atau pimpinan terhadap karyawan maka semakin meningkat komitmen karyawan.

Hasil uji statistik regresi logistik pengaruh sifat pekerjaan terhadap komitmen karyawan diperoleh 0,0009 artinya terdapat pengaruh yang signifikan antara sifat pekerjaan terhadap komitmen karyawan karena $p$-value kurang dari $\alpha=0,05$. Nilai 
$\operatorname{Exp}(B)=0,130$ artinya kecenderungan karyawan yang memiliki tingkat kepuasan tinggi terhadap sifat pekerjaan akan mempunyai tingkat komitmen cukup sebesar 7,69 (1/0,130) kali lebih besar jika dibandingkan dengan karyawan yang memiliki kepuasan terhadap sikap pekerjaan yang terkategori cukup. Hal ini menunjukkan semakin puas karyawan dengan sifat pekerjaan yang diperoleh dalam suatu instansi maka semakin bagus pula komitmennya terhadap instansi tersebut. Penelitian ini sejalan dengan penelitian yang dilakukan oleh Purwanti dan Anjarnako (2015) dengan hasil faktor atasan dan faktor pekerjaan secara parsial berpengaruh positif terhadap komitmen karyawan terhadap organisasi. Faktor atasan yang menentukan kepuasan kerja karyawan meliputi sikap atasan, kompetensi atasan, dukungan yang diberikan atasan dan kepedulian atasan dalam mendengarkan pendapat karyawan (Robbins \& Judge, 2008).

Sifat pekerjaan yang menjadi tanggung jawab karyawan harus disesuaikan agar tidak terlalu mudah dan tidak terlalu sulit bagi karyawan. Pekerjaan yang terlalu mudah menyebabkan karyawan mudah bosan dan kurang berkembang. Sebaliknya pekerjaan yang terlalu sulit dapat meningkatkan beban kerja yang jika berlangsung lama dapat mengakibatkan penurunan kepuasan kerja dan berdampak pada penurunan komitmen karyawan (Siagian, 2013). Faktor sifat pekerjaan adalah variabel kepuasan kerja yang memiliki nilai signifikansi paling tinggi dibandingkan empat faktor kepuasan kerja yang lain. Artinya sifat pekerjaan berpengaruh dominan terhadap komitmen karyawan Rumah Sakit Mata Undaan Surabaya.

\section{SIMPULAN}

Karyawan Rumah Sakit Mata Undaan Surabaya memiliki tingkat kepuasan kerja tinggi dan tingkat komitmen yang tinggi pula terhadap organisasi. Berdasarkan hasil uji pengaruh menunjukkan bahwa kepuasan kerja berpengaruh signifikan terhadap komitmen karyawan. Faktor kepuasan kerja yang berpengaruh signifikan terhadap komitmen karyawan adalah gaji, promosi, atasan dan sifat pekerjaan, sedangkan variabel rekan kerja tidak memiliki pengaruh yang signifikan terhadap komitmen karyawan. Sifat pekerjaan merupakan faktor yang berpengaruh dominan terhadap komitmen karyawan terhadap organisasi.

Komitmen karyawan Rumah Sakit Mata Undaan Surabaya yang sudah tinggi, sehingga dapat dipertahankan dan ditingkatkan dengan cara meningkatkan kepuasan kerja karyawan terutama pada sifat pekerjaan. Kesesuaian sifat pekerjaan dapat ditinjau dari ketepatan penerapan kelima dimensi pekerjaan yaitu variasi keterampilan, identitas tugas, signifikansi tugas, otonomi dan umpan balik pekerjaan bagi karyawan.

\section{DAFTAR PUSTAKA}

Allen, N. \& Meyer, J., 1990. The Measurement and Antecedents of Affective, Continuance and
Normative Commitment to the Organization. Journal of Occupational Psychology, pp. 1-18.

Cellucci, A. J. \& De Vries, D. L., 1978. Measuring Managerial Satisfaction: A Manual for MJSQ, United State: Center for Creative Leadership.

Fajri, A. N., Utami, H. N. \& Ruhana, I., 2015. Pengaruh Promosi terhadap Kepuasan Kerja dan Prestasi Kerja Karyawan (Studi pada Karyawan TP. Garam (Persero) Surabaya Jawa Timur). Jurnal Administrasi Bisnis (JAB), 21(1), pp. 67-76.

Gondokusumo, S. \& Sutanto, E. M., 2015. Motivasi, Kepuasan Kerja dan Komitmen Organisasional Karyawan. Jurnal manajemen dan kewirausahaan, 17(2), pp. 186-196.

Hasibuan, M. S. P., 2013. Manajemen Sumber Daya Manusia. Jakarta: Bumi Aksara.

Husniyawati, Y. R., 2016. Analisis Pengaruh Motivasi, Komitmen dan Faktor Organisasi terhadap Kinerja Kader Poysandu (Studi tentang Peningkatan Partisipasi lbu Balita di Posyandu Wilayah Kerja Puskesmas Sidotopo Wetan Kota Surabaya). In: Script. Surabaya: Universitas Airlangga.

Larasati, S. P. \& Haksama, S., 2016. Penerapan Theory of Contraint pada Kepuasan Kerja Karyawan Rumah Sakit Mata Undaan Surabaya. Jurnal Administrasi Kesehatan Indonesia, 4(2), pp. 155-162.

Luthans, F., 2006. Perilaku Organisasi. 10 ed. Yogyakarta: Andi.

Prabowo, A., Alamsyah, A. \& Noermijati, 2016. Pengaruh Kompensasi dan Kepuasan Kerja terhadap Komitmen Organisasional Perawat dan Bidan Kontrak di RS Bhayangkara Hasta Brata Batu Malang. Jurnal Aplikasi Manajemen, 14(1), pp. 58-67.

Prasanti, A. P., 2016. Analisis Pengaruh Penerapan Prinsip Total Quality Management terhadap Kepuasan Kerja Karyawan. In: Script. Surabaya: Universitas Airlangga.

Purwanti, E. \& Anjarnako, T. S., 2015. Pengaruh Faktor-Faktor Kepuasan Kerja terhadap Komitmen Organisasi Karyawan Bagian Administrasi pada PT. Perkebunan Nusantara $X$ (Persero) Unit Usaha PG. Toelangan - Sidoarjo. Jurnal Ekonomi dan Bisnis, 7(1), pp. 19-38.

Robbins, S. P. \& Judge, T. A., 2008. Organizational Behavior. 12 ed. Jakarta: Salemba Empat.

Robbins, S. P. \& Judge, T. A., 2013. Organizational Behavior. 15 ed. New Jersey: Pearson Education.

Siagian, P. S., 2013. Manajemen Sumber Daya Manusia. Jakarta: Bumi Aksara.

Sopiah, 2008. Perilaku Organisasional. Yogyakarta: Andi.

Tjiptono, F. \& Diana, A., 2003. Total Quality Management. Yogyakarta: Andi.

Utama, D. P. P. C. \& Wibawa, I. M. A., 2016. Pengaruh Kepuasan Kerja Terhadap Komitmen Organisasi dan Organizational Citizenship Behavior pada Karyawan Bali Rani Hotel. EJurnal Manajemen Universitas Udayana, 5(4), pp. 2511-2453. 